\title{
THE ANALYSIS OF IRREGULARITIES IN THE CALCULATION OF DEPRECIATION OF FIXED ASSETS IN THE REPUBLIC OF SERBIA
}

\author{
Milovan Stanišić, Zoran Petrović*, Kosana Vićentijević \\ Singidunum University, Faculty of Business in Belgrade, 32 Danijelova Street, Belgrade, Serbia
}

\section{Abstract:}

The paper discusses theoretical and practical aspects of calculating depreciation of fixed assets in the Republic of Serbia. The aim is to investigate the practice of calculating depreciation of fixed assets in enterprises in the Republic of Serbia in order to determine the possible failure (irregularities) that may affect the overall quality of financial reporting. Correct calculation of depreciation of fixed assets provides a realistic representation of depreciation expenses in the income statement and real value of fixed assets in the balance sheet. Based on the research conducted, the paper will reveal systemic irregularities in calculation of depreciation of fixed assets. In this sense, we believe that the content of the paper and conclusions arising from it will encourage accountants in various companies to change the way of calculating depreciation of fixed assets.
\end{abstract}

\section{INTRODUCTION}

Fixed assets form a significant part of the assets of business entities. Therefore, the proper calculation of their depreciation is a precondition for realistic financial reporting: realistic representation of depreciation expenses in the income statement and real value of fixed assets in the balance sheet.

The paper discusses theoretical and practical aspects of calculating depreciation of fixed assets in the Republic of Serbia from the perspective of the reality of calculated depreciation. The aim is to examine the practice of calculating depreciation of fixed assets in business entities in the Republic of Serbia in order to determine possible failures (irregularities) that affect the quality of financial reporting.

The following two factors contribute to realistic calculation of depreciation expenses of fixed assets:

1. the existence of relevant professional regulatory accounting procedures which regulate it;

2. the willingness and knowledge of the business entity to perform realistic calculation.

The paper will examine the following hypotheses:

$\mathrm{H} 1$ : accounting regulations applied in the Republic of Serbia provide realistic calculation of depreciation of fixed assets;

$\mathrm{H} 2$ : the share of fixed assets in total assets of business entities in the Republic of Serbia is significant;

H3: a significant number of business entities improperly uses the prescribed accounting principles for calculation of depreciation of fixed assets;

H4: tax regulation has a partially negative influence on the reality of calculating depreciation of land.
On each balance sheet data, the value at which property, plant and equipment are recognized in the balance sheet should be determined, which represents the value of their spending in that fiscal year (i.e. the amortization for that fiscal year) and, if necessary, their depreciation (which means that the recoverable amount of the asset should be determined) (Petrović, 2010). When the revaluation model is applied for subsequent evaluation, it is necessary to determine fair value of assets (Petrović, 2010).

\section{PROFESSIONAL REGULATION REQUIREMENTS AND REALITY OF CALCULATING DEPRECIATION OF FIXED ASSETS}

The following three regulations containing the guidelines for calculation of depreciation of fixed assets are applied in the Republic of Serbia for preparation of annual financial statements:

1. International Financial Reporting Standards (IFRS)

2. International Financial Reporting Standard for Small and Medium-Sized Entities (IFRS for SMEs) and

3. Rulebook on the method of recognition, evaluation, presentation and disclosure of positions in financial statements of micro and other legal entities ("RS Official Gazette" No.118/2013, 95/2014) - hereinafter Rulebook for micro and other legal entities.

We did not analyze the guidelines in the above regulations referring to the cases when a business entity has neither choice nor obligation to make an assessment such as in the guidelines for:

- the contents of the acquisition value of fixed assets;

- the time of the beginning and end of calculation period of depreciation of fixed assets. 
In the above-given regulations, we have analysed those guidelines for the calculation of depreciation of fixed assets that enable the business entity to provide the appropriate assessment required for a realistic calculation of depreciation for its assets. It is primarily about being able to estimate the remaining useful life of a particular asset and its residual value. Not only that all of these three regulations enable such estimations but also require from a business entity to check the remaining useful life of the asset and the estimated residual value at the end of the reporting period. For instance, in paragraph 51 of IAS 16 Property, plant and equipment, it is required from the entity to check the residual value and useful life of assets at least at the end of each financial year. If the expectations differ from the previous estimations, it is necessary to calculate the change in accordance with IAS 8 Accounting Policies, Changes in Accounting Estimates and Errors, i.e. to calculate it as a change in estimate. An identical requirement is contained in the:

1. paragraph 19 of section 17 of the Property, plant and equipment IFRS for SMEs, as well as in

2. Article 13 and Article 14 of the Rulebook for micro and other legal entities.

With respect to the above-mentioned regulation, entities are not limited in the realistic assessment of the real depreciation of fixed assets.

Besides that, these three regulations have the guidelines, which implies that depreciation has to be calculated separately for major parts of a fixed asset if these parts have significantly different patterns of spending economic benefits (for example, the aircraft's special depreciation for engines, especially for the fuselage; and even specifically calculated depreciation for separate parts of the fuselage, such as seats).

In relation to the aforementioned, accounting regulations of the Law on Corporate Income Tax of Legal Entities may indirectly affect the reality of calculating depreciation of land. Specifically, Article 10 of the Corporate Profit Tax Law does not envisage the possibility of calculating tax depreciation of land, which makes the business entities which need to calculate that kind of depreciation resort to inadequate accounting for the amount that would be amortized (for example, the cost of land classification is recorded in the account prepayments instead of being recorded in the carrying value of land).

\section{RESEARCH METHODOLOGY AND RESULTS}

The share of fixed assets in the total assets of business entities in the Republic of Serbia is significant. According to data published in the "Annual Financial Statements Bulletin 2014" (The Serbian Business Registers Agency, 2015) the share of fixed assets in the total assets of all business entities that have submitted data for statistical purposes in 2014 was $60.36 \%$, and the share of property, plant and equipment was $47.24 \%$. Thus, it can be concluded that the share of those assets that are subjected to depreciation is significant, which means that unrealistic accounting and depreciation may significantly jeopardize the reality of financial statements.

For the purposes of this study, we conducted a survey in September and October 2015. The primary data collection method was an anonymous questionnaire with different kinds of questions (open and closed). The questionnaires were distributed among the accountants of legal entities which have fixed assets. The poll was conducted on the ter- ritory of the following cities in the Republic of Serbia: Belgrade, Novi Sad, Subotica, Šabac, Niš and Valjevo. Table 1 presents the structure of the surveyed legal entities whose total number amounts to 123 legal entities. The answers from five questionnaires were not included in the analysis of the results because the questionnaire was not completed properly.

Table 1 . The size of the surveyed legal entities according to the "Accounting Law"

\begin{tabular}{cc}
\hline $\begin{array}{c}\text { The size of legal } \\
\text { entity }\end{array}$ & $\begin{array}{c}\text { The number of surveyed legal } \\
\text { entities }\end{array}$ \\
\hline Large & 20 \\
\hline Medium & 32 \\
\hline Small & 23 \\
\hline Micro & 43 \\
\hline Total & 118 \\
\hline
\end{tabular}

Table 2 shows that there are 27 entities subjected to financial statement auditing among the respondents for the year 2014. This is important because it emphasizes the contribution of auditing to the quality of financial reporting.

Table 2. Reporting entities in the structure of the surveyed legal entities

\begin{tabular}{cc}
\hline Reporting entities & The number of surveyed legal entities \\
\hline YES & 27 \\
\hline NO & 91 \\
\hline
\end{tabular}

The answers to some of the questions in the survey are cited and analyzed via the comments and graphs that follow.

1. Do you have fixed assets of large value (equipment, plant) whose book value is zero dinars and they are still actively used in business? The results show that 87 legal entities responded positively (Figure 1.)

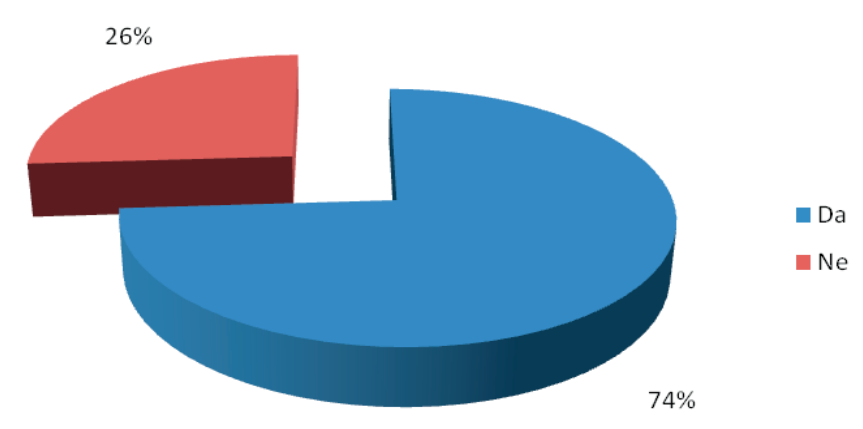

Figure 1. Using the large-value fixed assets whose book value is zero dinars

The conclusion based on the answers of the respondents is that the large-value fixed assets (equipment and plant) whose book value is zero dinars do exist and are actively used in business. It implies that at least two accounting mistakes have been made: a new projection of the remaining life of the asset has not been made and depreciation calculation does not include the residual value. The significant number of legal entities that have made this mistake causes a serious concern 
for the reality of financial statements, not only in recent years, but also in the years to come.

It is positive that the research results show that there is a relatively small frequency of these errors in legal entities subjected to financial statements auditing.

2. If you have fixed assets (equipment, plant) of great value whose book value is zero dinars and they are still actively used in business and if you are a reporting entity, what is the auditor's reaction to this situation? Table 3 shows that seven reporting entities reported that inadequate accounting for depreciation had an impact on external auditors' opinion.

Table 3. The impact of depreciation calculation on an audtior's opinion

\begin{tabular}{cc}
\hline $\begin{array}{l}\text { The impact of the depreciation calculation on } \\
\text { an auditor's opinion }\end{array}$ & replies \\
\hline YES & 7 \\
\hline NO & 20 \\
\hline
\end{tabular}

It is obvious that external auditors can significantly affect the reality of calculating depreciation of fixed assets.

3. Do you know that you have an obligation to check the remaining useful life and residual value of fixed assets at the end of each year and adjust them to the real situation and intended use of these assets?

The analysis of the answers to this question implied the following findings. Among the respondents, 103 accountants answered that they are familiar with this obligation, but they do not have any experience with such changes of data when calculating depreciation, nor there is an accounting practice in their legal entities that depreciation rates are changing.

It is positive that the research results show that a relatively large number of accountants are familiar with this obligation, but it is rather unfavourable that they have not used their knowledge to calculate depreciation in a more realistic way.

\section{SUMMARY}

On the basis of the research on the accounting and tax regulations relevant for calculating depreciation, as well as research on calculating depreciation practice in the Republic of Serbia we can conclude the following:

1. The accounting regulations applied in the Republic of Serbia provide a realistic calculation of depreciation of fixed assets - no matter whether IFRS, IFRS for SMEs or the Rulebook for micro and other legal entities is in question;
2. The share of fixed assets in total assets of business entities in the Republic of Serbia is significant - it is the additional reason for paying due attention to depreciation calculation of these assets;

3. A significant number of entities improperly use the prescribed accounting principles for calculation of depreciation of fixed assets - it is necessary to work on changing the accountants' approach towards accepting the legal (and required) assessment procedures for calculating depreciation of fixed assets;

4. The tax regulation has partially negative effects on the reality of calculating depreciation of land - it is possible to change relevant regulations of the Corporate Profit Tax Law so that it is not a limiting factor in the expression of the real depreciation of land.

In order to improve the financial reporting of legal entities in the Republic of Serbia, the contents and conclusions in this paper should encourage accounting experts to implement methods that provide a more realistic calculation of depreciation.

\section{REFERENCES}

Agencija za privredne registre Republike Srbije. (2015). Godišnji bilten finansijskih izveštaja 2014. Datum preuzimanja 05.11.2015. http://www.apr.gov.rs/Portals/0/GFI/ Makrosaopstenja/2014/Godisnji\%20bilten\%20FI\%202014. pdf?ver=2015-10-30-142557-660

IFRS. (2015). IAS 8 Accounting Policies, Changes in Accounting Estimates and Errors. Datum preuzimanja 05.11.2015. http:// www.ifrs.org/IFRSs/Pages/IFRS.aspx

IFRS. (2015). IAS 16 Property, Plant and Equipment. Datum preuzimanja 05.11.2015. http://www.ifrs.org/IFRSs/Pages/IFRS.aspx

IFRS. (2015). IFRS for SMEs. Datum preuzimanja 05.11.2015. http:// www.ifrs.org/IFRS-for-SMEs/Pages/IFRS-for-SMEs.aspx

Petrović, Z. (2010). Finansijsko izveštavanje. Beograd: Univerzitet Singidunum.

Službeni glasnik RS. (2013). Pravilnik o načinu priznavanja, vrednovanja, prezentacije i obelodanjivanja pozicija u pojedinačnim finansijskim izveštajima mikro i drugih pravnih lica. Službeni glasnik RS, br. 118/2013 i 95/2014.

Službeni glasnik RS. (2001). Zakon o porezu na dobit pravnih lica. Službeni glasnik RS, br. 25/2001, 80/2002, 80/2002 (dr. zakon), 43/2003, 84/2004, 18/2010, 101/2011, 119/2012, 47/2013, 108/2013, 68/2014 (dr. zakon), 142/2014 i 91/2015.

Službeni glasnik RS. (2013). Zakon o računovodstvu. Službeni glasnik RS br. 62/2013.

\section{ISTRAŽIVANJE NEPRAVILNOSTI U OBRAČUNU AMORTIZACIJE STALNIH SREDSTAVA U REPUBLICI SRBIJI}

\section{Apstrakt:}

Ovaj rad bavi se teorijskim i praktičnim aspektima obračuna amortizacije stalnih sredstava u Republici Srbiji. Cilj rada jeste da se ispita praksa obračuna amortizacije stalnih sredstava u privrednim subjektima u Republici Srbiji radi utvrđivanja eventualnih propusta (nepravilnosti) koji utiču na kvalitet finansijskog izveštavanja. Pravilan obračun amortizacije stalnih sredstava obezbeđuje realno iskazivanje troškova amortizacije u bilansu uspeha i realnu vrednost stalnih sredstava u bilansu stanja. Oslanjajući se na sprovedeno istraživanje, autori će pokušati da utvrde sistemske nepravilnosti u obračunu amortizacije stalnih sredstava. U tom smislu, smatramo da će sadržaj rada i zaključci uticati na računovođe da promene način utvrđivanja amortizacije stalnih sredstava.
Ključne reči:

amortizacija,

finansijsko izveštavanje, troškovi. 